\title{
An IoT based Green Home Architecture for Green Score Calculation towards Smart Sustainable Cities
}

\author{
K. Manikanda Kumaran ${ }^{1 *}$, M. Chinnadurai ${ }^{2}$, S. Manikandan' ${ }^{1}$, S. Palani Murugan², E. Elakiya ${ }^{2}$ \\ ${ }^{1}$ Department of Information Technology, E.G.S. Pillay Engineering College, \\ Nagapattinam, Tamil Nadu, India. \\ ${ }^{2}$ Department of Computer Science and Engineering, E.G.S. Pillay Engineering College, \\ Nagapattinam, Tamil Nadu, India. \\ [e-mail: mail2kmkk@gmail.com] \\ ${ }^{*}$ Corresponding author: K.Manikanda Kumaran
}

Received January 7, 2021; revised May 26, 2021; accepted June 9, 2021; published July 31, 2021

\begin{abstract}
In the recent modernized world, utilization of natural resources (renewable $\&$ non-renewable) is increasing drastically due to the sophisticated life style of the people. The over-consumption of non-renewable resources causes pollution which leads to global warming. Consequently, government agencies have been taking several initiatives to control the over-consumption of non-renewable natural resources and encourage the production of renewable energy resources. In this regard, we introduce an IoT powered integrated framework called as green home architecture (GHA) for green score calculation based on the usage of natural resources for household purpose. Green score is a credit point (i.e.,10 pts) of a family which can be calculated once in a month based on the utilization of energy, production of renewable energy and pollution caused. The green score can be improved by reducing the consumption of energy, generation of renewable energy and preventing the pollution. The main objective of GHA is to monitor the day-to-day usage of resources and calculate the green score using the proposed green score algorithm. This algorithm gives positive credits for economic consumption of resources and production of renewable energy and also it gives negative credits for pollution caused. Here, we recommend a green score based tax calculation system which gives tax exemption based on the green score value. This direct beneficiary model will appreciate and encourage the citizens to consume fewer natural resources and prevent pollution. Rather than simply giving subsidy, this proposed system allows monitoring the subsidy scheme periodically and encourages the proper working system with tax exemption rewards. Also, our GHA will be used to monitor all the household appliances, vehicles, wind mills, electricity meter, water re-treatment plant, pollution level to read the consumption/production in appropriate units by using the suitable sensors. These values will be stored in mass storage platform like cloud for the calculation of green score and also employed for billing purpose by the government agencies. This integrated platform can replace the manual billing and directly benefits the government.
\end{abstract}

Keywords: Cloud Computing, green energy, green home system, Internet of things, smart sustainable city, smart taxation, wireless sensor network. 


\section{Introduction}

C limate change is the greatest threat to humanity today. The drastic change in the worldwide climate is straightforwardly brought out by human behaviour particularly in urban communities, which accelerates the most noteworthy greenhouse gases (GHG) throughout the world [1]. Urban areas' little topographical impression gives a false representation of their criticalness. They cover 2 percent of the world's landmass; however, it represents the majority of the total populace, financial action, and energy usage. Here, we centre on the third perspective-energy use-as urban communities and inexhaustible power respectively, that will be the natural surroundings and the choice of energy worldwide. The two are progressively undividable [2]. Studies additionally have indicated that GHG have ascribed to worst climate and changes to nature and humanity [1]. As per [1], electrical power and heat generation added to $25 \%$ of the most elevated amount of total worldwide GHG discharge. As the urban areas grow, their energy usage also grows which leads to the contamination of sources. These features focus the significance and necessity of sustainable energy utilization to decrease GHG outflows.

As the urban communities attempt to become smart, the renewable energy source does a vital function in assisting them with accomplishing their environment reliable energy objectives. The objectives of a people-focused smart city are financial development, supportability, and sophistication, while the objectives of a utility ensure consistent, moderate, and environment conscientious energy [2]. Smart-city provisions, such as air quality observation, efficient usage of energy, electricity and water, tracking of wastes can create good results, for example, 10-15\% less GHG discharges, 30-130 less kilograms of solid waste per individual every year, and 25-80 litres of water spared per individual per day [2].

Smart urban areas generally share an interest in conveying renewable energy sources in smart homes with the assistance of technologies that line up with their objectives. The evolution of smart home progress is beyond the innovation and implementation for peoplefocused core interest. The primary phase of the smart home journey includes coordinating with the Internet of Things (IoT) innovations, for example, sensors, with existing foundation to make noteworthy information [3][4].

Thusly, notwithstanding smartening their grids, utilities can use their framework to serve smart city activities in zones outside of energy, dodging exorbitant duplication. For instance, a utility's smart meters can be outfit to distinguish water leaks; smart transformers can have air quality sensors; and smart streetlamps can be expanded with charging stations, camcorders, $\mathrm{Wi}-\mathrm{Fi}$, and sensors to gather information on anything from vehicles and passer-by in the traffic eg., parking space accessibility. Utilities additionally have an association with practically every home and business, to which they can broaden smart city activities by means of smart home frameworks [4].

Sometime, the technologies and gathered information may not conclusively end up and being valuable or significant for limiting the non-renewable energy utilization which prompts global warming. Consequently, government agencies have been taking several initiatives to control the overconsumption of non-renewable natural resources and encourage the production of renewable energy resources. Rather than simply giving subsidy, our proposed model allows monitoring the subsidy scheme periodically and encourages the proper working with tax exemption rewards.

The objective of this work is to improve the household energy independence, to empower people to use renewable resources, for reducing the emissions of greenhouse gas, and encourage economic growth by tax waiving or exemption. 
Our contributions in this paper are listed below,

a) We introduce an IoT powered integrated Green Home Architecture for monitoring the consumption of natural resources, production of renewable resources and pollution caused by every household in the smart city.

b) We propose a novel green score algorithm which gives positive credits for economic consumption of resources, production of renewable energy and the negative credits will be given for pollution causes.

c) A green score based tax exemption/concession scheme is introduced to encourage the households by tax exemption/concession based on the good green score value.

The Fig. 1 describes the goals, influential and technologies employed on the proposed green score framework. The rest of the paper is presented as follows. Section 2 explains our motivation of proposed work based on the literature survey. This leads us to Section 3, where we provide the green home architecture. In Section 4, a green score algorithm is proposed using the green home architecture which is motivated from the surveyed literature. This is followed by the simulation of the proposed algorithm for two different scenarios in Section 5. Section 6 deals with the recommendations of revised tax based on the obtained green score. Finally, we conclude our paper in Section 8.

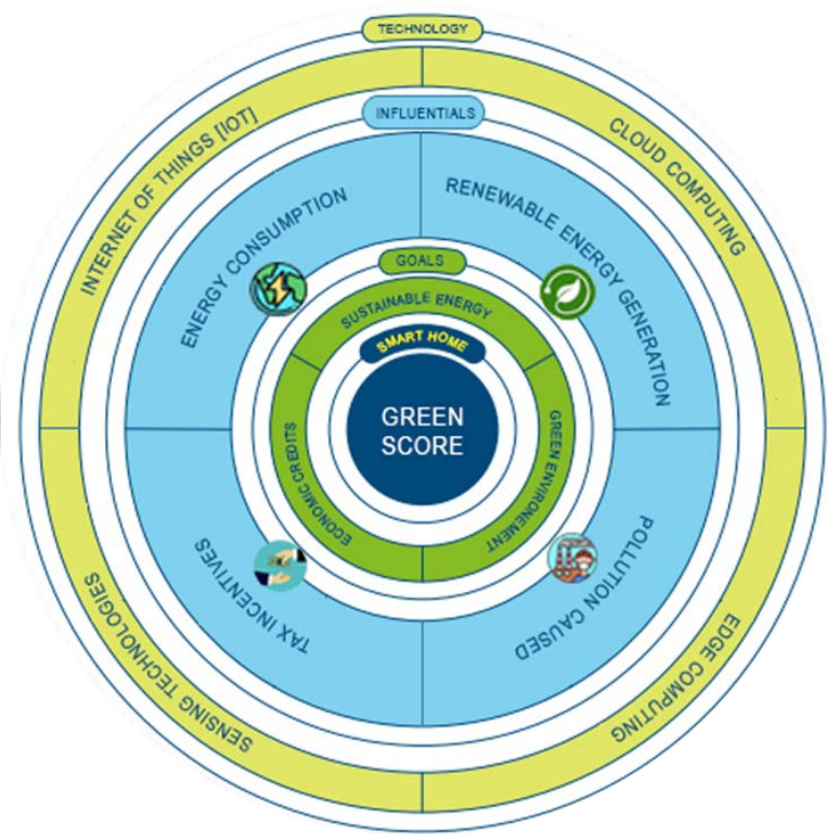

Fig. 1. Goals, influential and technologies of the proposed green score framework.

\section{Literature Survey}

The internet of things [IoT] is a fresh communication and network exemplar, and different investigations of the IoT have been led on smart city scenario [5][6]. Fortino et al. [7] proposed a multi-layered agent-based engineering for the advancement of proactive, collaborating, and context aware smart objects through a JADE-based middleware. The multi-layered agentbased engineering leads to a wide scope of smart objects from reactive to proactive, from little to enormous, and from autonomous to social. Gubbi et al. [8] present another vision for 
Internet of Things based on cloud. This paper examined key empowering advancements and utilizations of IoT. Cirani et al. [9] proposed a versatile and self-designing engineering for huge scope of IoT. This engineering can offer self-governing types of assistance and asset disclosure components with no human intercession to smart objects.

Numerous investigations have been directed with expanding the significance of energy issues, on the energy management framework. Different investigations of a ZigBee-based HEMS have been done in the field of consumer gadgets [10][11][12]. The proposed ZigBeebased HEMSs in these examinations use IEEE 802.15.4 (ZigBee) as the norm for individual zone remote organizations to build HANs. Fortino et al. [13] introduced the system for multiplatform space based on remote sensor and actuator organizations (WSANs) for empowering productive and viable building management.

Niyato et al. [14] introduced machine-to-machine (M2M) correspondences and organization design for a HEMS to assemble energy utilization demand and status from home apparatuses. Hu and Li [15] introduced a hardware design and usage of smart HEMS (SHEMS) with the elements of sensing, communications, and AI. Several routing schemes are introduced for ad hoc sensor communication protocols [16][17] which can suite for our proposed scenario.

The renewable energy plays a very small role in the world's energy supply, accounting for only around 10 percent of the overall energy demand as described in the Fig. 2.

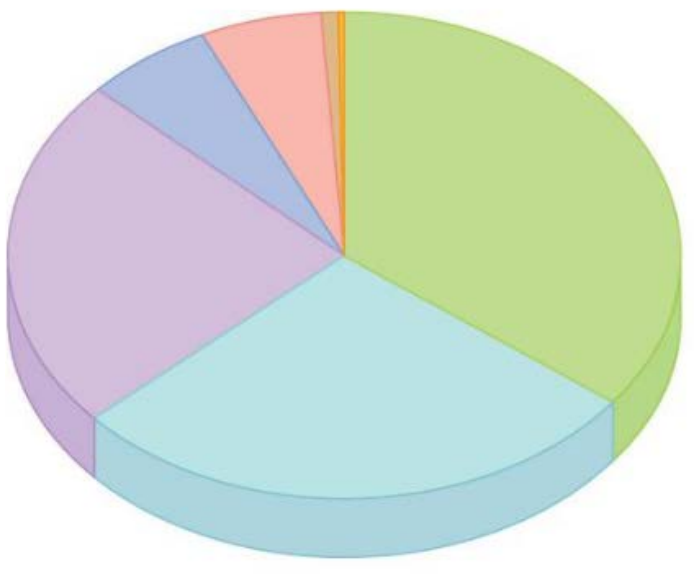

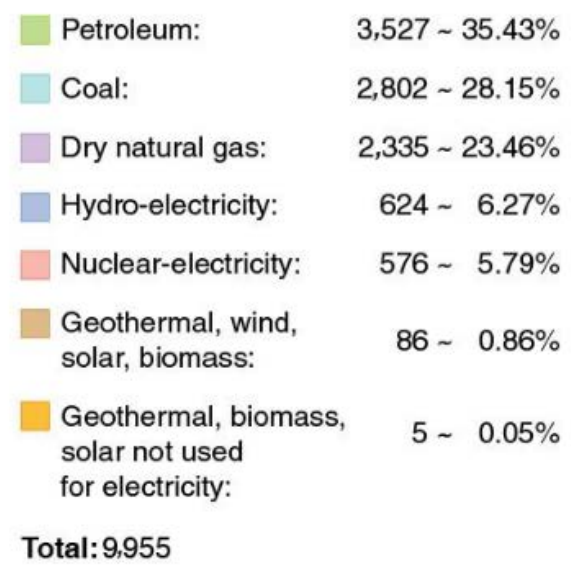

Fig. 2. World energy consumption by source, in billions of kilowatt-hours [18].

All the above-mentioned frameworks and technologies are empowered to monitor, and even minimize the energy utilization [19][20] but never ever encourage or concentrate on the generation of renewable energy at smart homes that make them self-sufficient on energy and the financial rewards or incentives for balancing the need and generation of energy.

The smart cities have possible technological support to implement a novel integrated framework to monitor and alert the citizens about their day-to-day energy usage. By just monitoring and alerting the people, the non-renewable energy usage level will not be reduced. Thus, we introduce a green score algorithm based Green Home framework which not only monitors the energy usage but also encourages the production of renewable energy resources by giving financial credits.

Using our proposed green home architecture, the energy consumption of every home is monitored and gives financial rewards in the way of tax exemption for the generation and efficient consumption of renewable and non-renewable energies respectively. This will 
encourage the people to generate renewable energies like wind, solar, bio-gas etc. at home for the household purposes and it makes them energy self-sufficient. By increasing the renewable energy production, the renewable energy usage will tend to decrease gradually and obviously results less $\mathrm{CO} 2$ emission which will lead to tremendous fall in pollution and greenhouse effect.

All the subsidies are given/sanction only for the deployment of renewable energy objects or source components [21][22][23]. In the post installation, there is no proper maintenance follow up for ensuring the proper working of the subsidy source components. Hence, we also require a framework for continuous monitoring of the proper utilization of subsidy units for the renewable energy generation and give credits for the proper maintenance. Thus, our proposed green home framework is employed for green score calculation which can monitor the working condition of the renewable energy generation units and update the status to the government funded agencies. This follows up process ensures the proper working and prolonged lifetime of the renewable energy generation units.

\section{Overview of System Architecture}

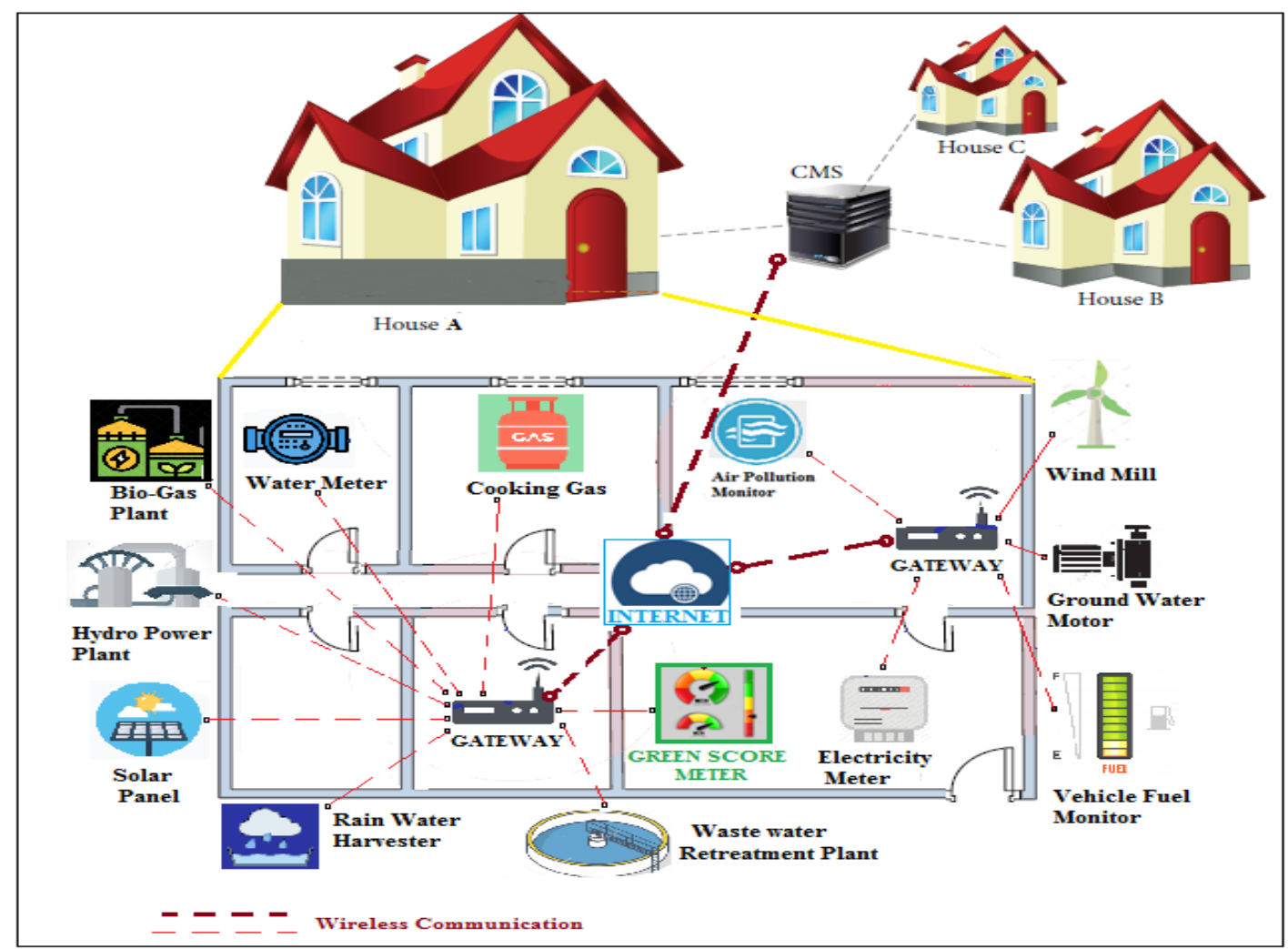

Fig. 3. The proposed Green Home Architecture.

Fig. 3 shows the typical green home architecture (GHA). The GHA is constructed by using various wired and wireless network technologies. The various network-based devices in the home, such as smart electricity meter, water monitor, vehicle fuel monitor, green score meter, electricity generation monitor, air pollution monitor, gas monitor, electricity generation meter, are connected by the gateways (GW) in GHA. The appropriate sensors are deployed in the network-based monitors to observe the energy usage and generation. The GWs have some 
roles of aggregating data from the networked devices and transmitting the data to the cloud storage.

These GWs are dynamic and are essential network components for reliable transmission in the GHA. Although this static network architecture enhances reliability of communication, it reduces scalability of networks, systems, and services.

The dynamic GWs, moreover, have another advantage of energy efficiency. In the proposed GHA, the GW's power not needed to be always-on for collecting the data from sensors over the HAN. Here, the mobile device is used as a service provider, as well as the network resources. We use the wi-fi and bluetooth technology for communications as well, because recently most mobile devices have adopted bluetooth as a main wireless personal area network (WPAN). In this way, it is possible to construct GHAs without installing additional GWs and transmitting the data to the cloud database. The resource utilization of the particular family can be retrieved monthly from the same cloud database for the green score calculation.

These values are stored in a mass storage platform like cloud which is employed for the calculation of green score and billing purpose by the government agencies. This integrated platform can replace the manual billing, and directly benefits the government.

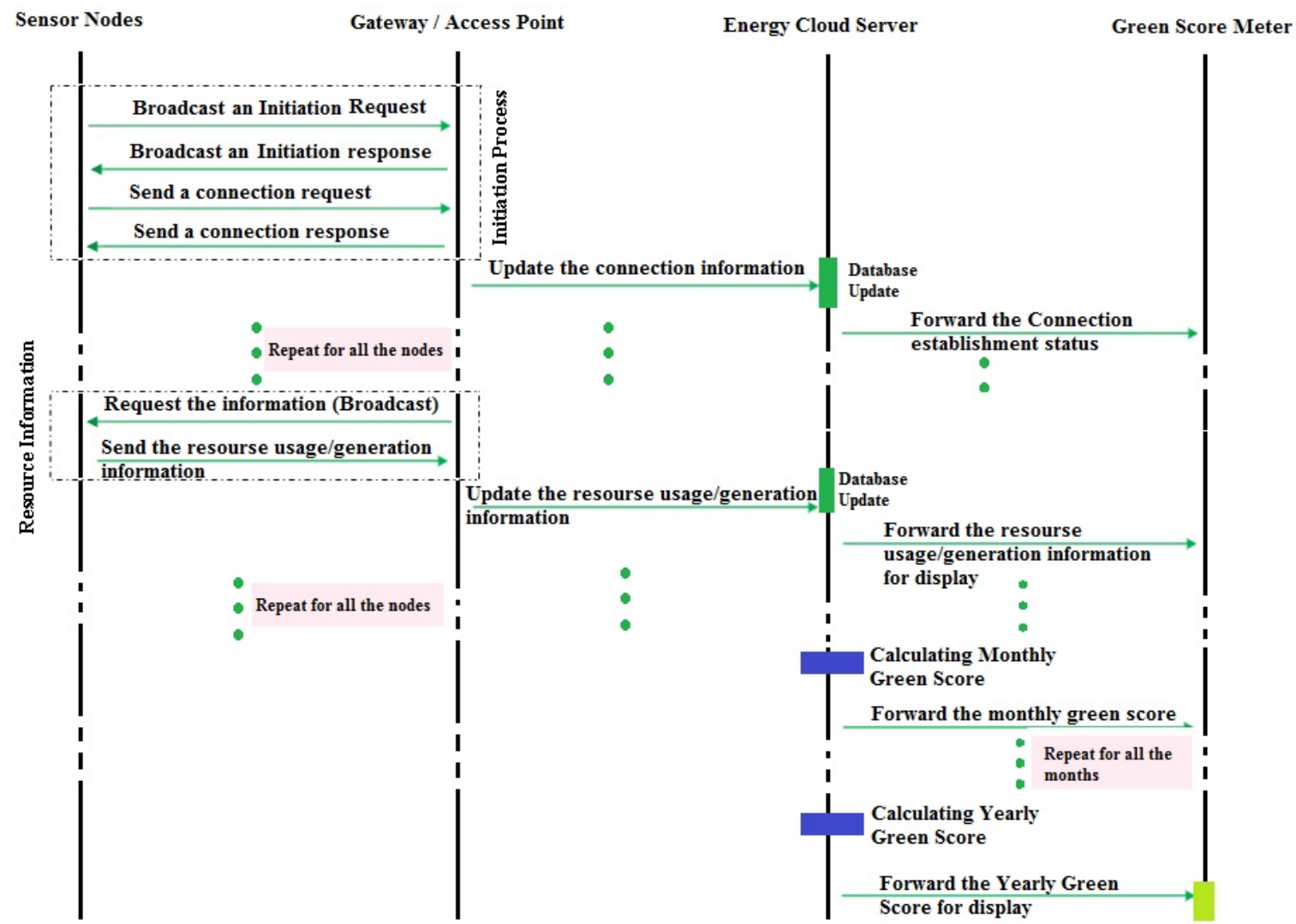

Fig. 4. Sequence diagram of green score calculation in green home architecture.

Fig. 4 shows a sequence diagram of the initiation and connection processes between the sensor nodes and the cloud server through access point/gateway. Further it shows the information passage of nodes connection status, resource usage/generation information and green score between the cloud server and green score meter for display. 


\section{Green Score Algorithm}

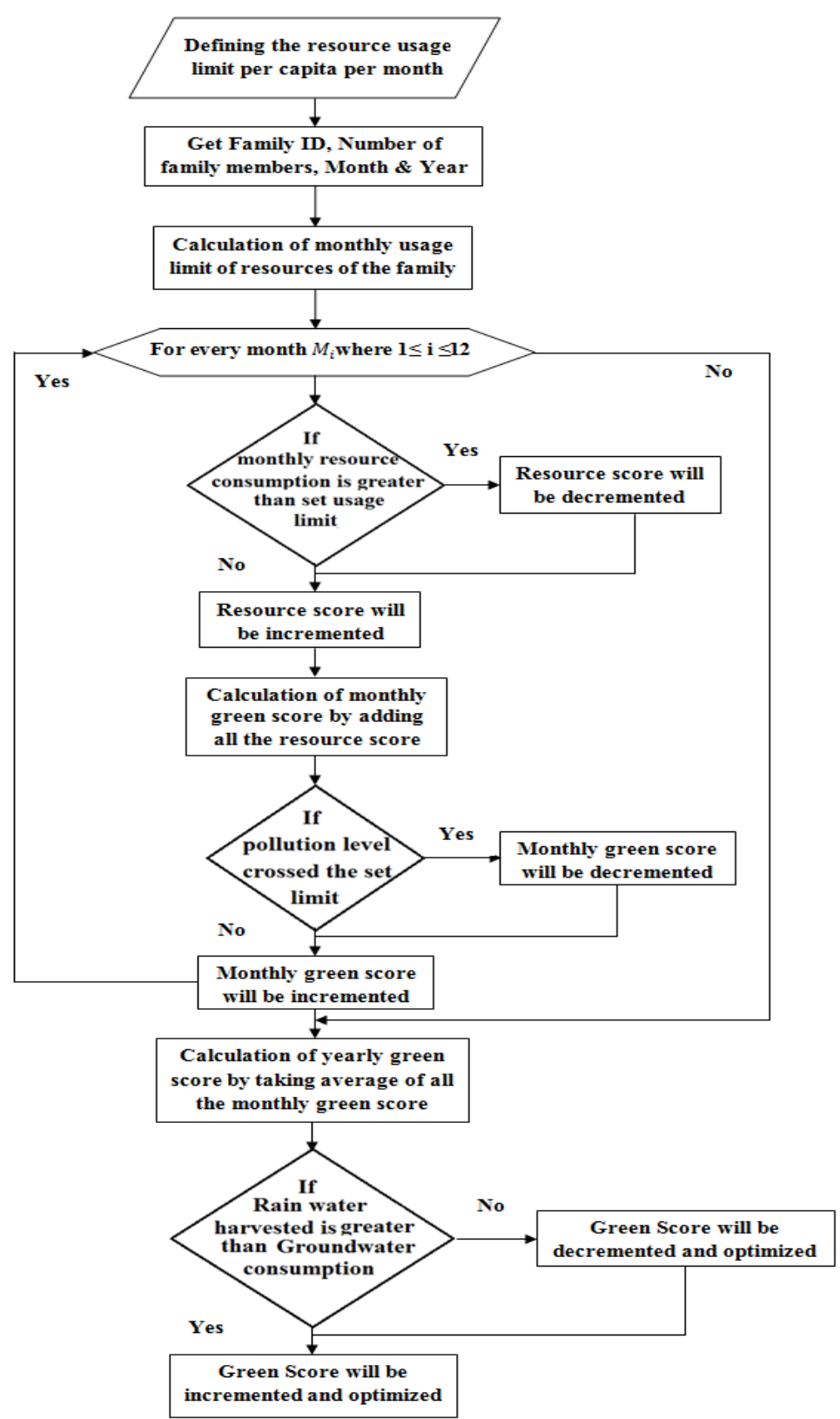

Fig. 5. Flowchart of the optimal green score calculation.

Here, we introduce an IoT powered green home architecture for green score calculation based on the usage of natural resources for household purpose. As in the Fig. 5, the monthly green score (GSM) is a credit point (i.e.,10 pts) of a family which can be calculated monthly based on energy utilization, renewable energy generation and pollution caused during that month. The green score calculated monthly can be displayed to the user and also updated on the database. The yearly green score GSY $\left(\mathrm{Y}_{\mathrm{i}}\right)$ can be further calculated by taking average of the monthly green score. Green score algorithm gives positive credits for economic consumption 
of resources and generation of renewable energy. The negative credits will be given for pollution causing and excess ground water consumption.

As in equation 1, GSM is the difference between the sum of electricity score ES, water score WS, natural gas score NGS, crude oil score COS, renewable energy score RES and the sum of air pollution sore APS and ground water GWS.

$$
\mathrm{GSM}=\mathrm{ES}+\mathrm{WS}+\mathrm{NGS}+\mathrm{COS}+\mathrm{RES}-\mathrm{APS}-\mathrm{GWS}
$$

Initially, the monthly usage limit per capita has to be set for electricity $E_{P P M}$, water $\mathrm{WL}_{\mathrm{PPM}}$, natural gas NGLPPM and crude oil $\mathrm{COL}_{\mathrm{PPM}}$. Based on the geographical location, monthly usage limit can differs based on the seasons throughout the year. The Electricity usage limit allowed for a family per month $\mathrm{EL}_{\mathrm{FM}}$ can be estimated by multiplying the monthly usage limit of electricity per capita $E_{P P M}$ with the number of persons in the family $\mathrm{N}_{\mathrm{P}}$.

$$
\mathrm{EL}_{\mathrm{FM}}=\mathrm{EL}_{\mathrm{PPM}} \times \mathrm{N}_{\mathrm{P}}
$$

Likewise, the water usage limit allowed for a family per month $\mathrm{WL}_{\mathrm{FM}}$ can be calculated by multiplying the monthly usage limit of water per capita $\mathrm{WL}_{\mathrm{PPM}}$ with the number of persons in the family $\mathrm{N}_{\mathrm{P}}$.

$$
\mathrm{WL}_{\mathrm{FM}}=\mathrm{WL}_{\mathrm{PPM}} \times \mathrm{N}_{\mathrm{P}}
$$

The cooking gas limit allowed for a family per month $\mathrm{NGL}_{\mathrm{FM}}$ can be calculated by multiplying the monthly usage limit of natural gas per capita NGL $L_{P P M}$ with the number of persons in the family $\mathrm{N}_{\mathrm{P}}$.

$$
\mathrm{NGL}_{\mathrm{FM}}=\mathrm{NGL}_{\mathrm{PPM}} \times \mathrm{N}_{\mathrm{P}}
$$

The vehicle fuel/oil usage limit allowed for a family per month $\mathrm{COL}_{\mathrm{FM}}$ can be calculated by multiplying the monthly usage limit of crude oil per capita $\mathrm{COL}_{\mathrm{PPM}}$ with the number of persons in the family $\mathrm{N}_{\mathrm{P}}$.

$$
\mathrm{COL}_{\mathrm{FM}}=\mathrm{COL}_{\mathrm{PPM}} \times \mathrm{N}_{\mathrm{P}}
$$

Once the usage limit of resources is set for the family, the monthly green score has to be initiated. In this method, the resources consumed by the family have to be compared with the set limit and based on this respective credit will be given to the family. In this regard, if the monthly $\mathrm{M}_{\mathrm{i}}$ electricity consumption of a family $\mathrm{EC}_{\mathrm{FPM}}\left(\mathrm{M}_{\mathrm{i}}\right)$ is lower than the electricity usage limit $E L_{F M}$ allowed for a family per month $M_{i}$ then the electricity score of the month $E S\left(M_{i}\right)$ can be incremented by 1 . Likewise, Water consumption $\mathrm{WC}_{\mathrm{FPM}}\left(\mathrm{M}_{\mathrm{i}}\right)$ of the month is compared with monthly water limit $\mathrm{WL}_{\mathrm{FM}}\left(\mathrm{M}_{\mathrm{i}}\right)$. If $\mathrm{WC}_{\mathrm{FPM}}\left(\mathrm{M}_{\mathrm{i}}\right) \leq \mathrm{WL}_{\mathrm{FM}}$, then $\mathrm{WS}\left(\mathrm{M}_{\mathrm{i}}\right)$ is incremented by 1 or else $W S\left(M_{i}\right)=0$. Subsequently, if the natural gas consumption of a family per month $\operatorname{NGC}_{\mathrm{FPM}}\left(\mathrm{M}_{\mathrm{i}}\right)$ is lower than the natural gas limit allowed for a family per month $\mathrm{NGL}_{\mathrm{FM}}$ then the natural gas score of the month NGS $\left(\mathrm{M}_{\mathrm{i}}\right)$ can be incremented by 1. Similarly, crude oil consumption $\mathrm{CO}_{\mathrm{FPM}}\left(\mathrm{M}_{\mathrm{i}}\right)$ of the month is compared with monthly crude oil limit $\mathrm{CO}_{\mathrm{FM}}\left(\mathrm{M}_{\mathrm{i}}\right)$. If $\mathrm{CO}_{\mathrm{FPM}}\left(\mathrm{M}_{\mathrm{i}}\right) \leq \mathrm{CO}_{\mathrm{FM}}$, then $\operatorname{COS}\left(\mathrm{M}_{\mathrm{i}}\right)$ is incremented by 1 or else $\operatorname{COS}\left(\mathrm{M}_{\mathrm{i}}\right)=0$.

The renewable energies produced in a home are considered to be solar, wind and hydroelectric energies. The renewable energy production of a family $\mathrm{REP}_{\mathrm{FM}}$ for the month $\mathrm{M}_{i}$ can 
be estimated by summing the energy produced by the solar $\mathrm{SEP}_{\mathrm{FM}}$, wind $\mathrm{WEP}_{\mathrm{FM}}$ and hydroelectric energy $\mathrm{HEP}_{\mathrm{FM}}$ for the month $\mathrm{M}_{\mathrm{i}}$ as in the equation below,

$$
\operatorname{REP}_{\mathrm{FM}}\left(\mathrm{M}_{\mathrm{i}}\right)=\operatorname{SEP}_{\mathrm{FM}}\left(\mathrm{M}_{\mathrm{i}}\right)+\operatorname{WEP}_{\mathrm{FM}}\left(\mathrm{M}_{\mathrm{i}}\right)+\operatorname{HEP}_{\mathrm{FM}}\left(\mathrm{M}_{\mathrm{i}}\right)
$$

Now, $\mathrm{REP}_{\mathrm{FM}}$ have to be compared with $\mathrm{EC}_{\mathrm{FPM}}$ to estimate renewable energy score RES. If $\operatorname{REP}_{\mathrm{FM}}\left(\mathrm{M}_{\mathrm{i}}\right)$ is greater than $75 \%$ of $\operatorname{EC}_{\mathrm{FPM}}\left(\mathrm{M}_{\mathrm{i}}\right)$, then RES $\left(\mathrm{M}_{\mathrm{i}}\right)$ can be incremented by 3 . If $\operatorname{REP}_{\mathrm{FM}}\left(\mathrm{M}_{\mathrm{i}}\right)$ is lesser than $75 \%$ of $\mathrm{EC}_{\mathrm{FPM}}\left(\mathrm{M}_{\mathrm{i}}\right)$, then we have to compare individual renewable resources $\mathrm{SEP}_{\mathrm{FM}}, \mathrm{WEP}_{\mathrm{FM}}$ and $\mathrm{HEP}_{\mathrm{FM}}$ with the energy consumed $\mathrm{EC}_{\mathrm{FPM}}$ to estimate RES for individual renewable resource respectively. For that, if $\operatorname{SEP}_{\mathrm{FM}}\left(\mathrm{M}_{\mathrm{i}}\right)$ is greater than $25 \%$ of $\operatorname{EC}_{\mathrm{FPM}}\left(\mathrm{M}_{\mathrm{i}}\right)$, the RES $\left(\mathrm{M}_{\mathrm{i}}\right)$ isincremented by 1 . Subsequently, if $\mathrm{WEP}_{\mathrm{FM}}\left(\mathrm{M}_{\mathrm{i}}\right)$ is greater than $25 \%$ of $\mathrm{EC}_{\mathrm{FPM}}\left(\mathrm{M}_{\mathrm{i}}\right)$, the RES $\left(\mathrm{M}_{\mathrm{i}}\right)$ isincremented by 1 . If $\operatorname{HEP}_{\mathrm{FM}}\left(\mathrm{M}_{\mathrm{i}}\right)$ is greater than $25 \%$ of $\mathrm{EC}_{\mathrm{FPM}}\left(\mathrm{M}_{\mathrm{i}}\right)$, the $\operatorname{RES}\left(\mathrm{M}_{\mathrm{i}}\right)$ is incremented by 1 .

Then the Bio-gas production of a family for a month $\mathrm{BGP}_{\mathrm{FM}}\left(\mathrm{M}_{\mathrm{i}}\right)$ has to be compared with NGS $\left(M_{i}\right)$ to estimate natural gas score NGS $\left(M_{i}\right)$ of the month $M_{i}$. Likewise, If $\operatorname{BGP}_{\mathrm{FM}}\left(\mathrm{M}_{\mathrm{i}}\right) \geq 25 \%$ of $\operatorname{NGC}_{\mathrm{FPM}}\left(\mathrm{M}_{\mathrm{i}}\right)$, the increase is NGS $\left(\mathrm{M}_{\mathrm{i}}\right)$ by 1 . The water retreated of a family $\mathrm{WR}_{\mathrm{FM}}\left(\mathrm{M}_{\mathrm{i}}\right)$ for month $\mathrm{M}_{\mathrm{i}}$ has compared with $\mathrm{WC}_{\mathrm{FPM}}\left(\mathrm{M}_{\mathrm{i}}\right)$ to estimate water score $\mathrm{WS}\left(\mathrm{M}_{\mathrm{i}}\right)$ of the month $\mathrm{M}_{\mathrm{i}}$. Similarly, if $\mathrm{WR}_{\mathrm{FM}}\left(\mathrm{M}_{\mathrm{i}}\right) \geq 25 \%$ of $\mathrm{WC}_{\mathrm{FPM}}\left(\mathrm{M}_{\mathrm{i}}\right)$, the $\mathrm{WS}\left(\mathrm{M}_{\mathrm{i}}\right)$ is increased by 1 .

Now, the air pollution level and the air pollution score can be monitored and calculated based on the pollution caused by the family $\mathrm{APC}_{\mathrm{FM}}$. If $\mathrm{APC}_{\mathrm{FM}}$ is greater than the Air pollution limit allowed for a family per month APL $L_{F M}$, the air pollution score $\operatorname{APS}\left(\mathrm{M}_{\mathrm{i}}\right)$ for the month $\mathrm{M}_{\mathrm{i}}$ is incremented by 1 .

Now the green score GSM of the month $\mathrm{M}_{\mathrm{i}}$ can be calculated using the following equation,

$$
\operatorname{GSM}\left(M_{i}\right)=E S\left(M_{i}\right)+\operatorname{WS}\left(M_{i}\right)+\operatorname{NGS}\left(M_{i}\right)+\operatorname{COS}\left(M_{i}\right)+\operatorname{RES}\left(M_{i}\right)-\operatorname{APS}\left(M_{i}\right)
$$

The yearly green score GSY $\left(\mathrm{Y}_{\mathrm{i}}\right)$ can be calculated by taking average of GSM $\left(\mathrm{M}_{\mathrm{i}}\right)$ of all the 12 months.

$$
\operatorname{GSY}\left(Y_{i}\right)=\frac{\sum_{i=1}^{n} G S Y\left(M_{i}\right)+G S Y\left(M_{i+1}\right)+\ldots . .+G S Y\left(M_{n}\right)}{n}
$$

where $n=12$, denotes the twelve months of the evaluation year.

Once the yearly green score GSY $\left(\mathrm{Y}_{\mathrm{i}}\right)$ calculated, the optimal green score OGSY $\left(\mathrm{Y}_{\mathrm{i}}\right)$ can be estimated by comparing the rain water harvest score $\mathrm{RWHS}\left(\mathrm{Y}_{\mathrm{i}}\right)$ and Ground water score $\mathrm{GWS}\left(\mathrm{Y}_{\mathrm{i}}\right)$ based on the comparison, two scenarios as described below,

- Scenario $1\left(\mathrm{RWH}\left(\mathrm{Y}_{\mathrm{i}}\right)<\mathrm{GWC}\left(\mathrm{Y}_{\mathrm{i}}\right)\right)$

- Scenario $2\left(\mathrm{RWH}\left(\mathrm{Y}_{\mathrm{i}}\right)>\mathrm{GWC}\left(\mathrm{Y}_{\mathrm{i}}\right)\right)$

The yearly green score which is estimated earlier can be optimized either by any one of the two scenarios listed above.

\subsection{Scenario 1}

If the yearly ground water consumption $\mathrm{GWC}\left(Y_{i}\right)$ is higher than the rain water harvested RWH $\left(Y_{i}\right)$ during the same year $\left(Y_{i}\right)$, the ground water score will be raised to 1 . Now, the optimal green score can be optimized by deducting $G W S\left(Y_{i}\right)$ from GSY $\left(Y_{i}\right)$ as in the equation. 
if RWH $\left(Y_{i}\right)<\mathrm{GWC}\left(Y_{i}\right)$, then $G W S\left(Y_{i}\right)=1$

Then OGSY $\left(Y_{i}\right)=\operatorname{GSY}\left(Y_{i}\right)-G W S\left(Y_{i}\right)$

\subsection{Scenario 2}

If the yearly rain water harvested RWH $\left(Y_{i}\right)$ is higher than the ground water consumption $\operatorname{GWC}\left(Y_{i}\right)$ of the same year $\left(Y_{i}\right)$, the rain water harvest score RWHS will be raised to 1 . Now, the optimal green score can be optimized by adding $\operatorname{RWHS}\left(Y_{i}\right)$ with GSY $\left(Y_{i}\right)$ as in the equation.

if RWH $\left(Y_{i}\right)>\operatorname{GWC}\left(Y_{i}\right)$, then $\operatorname{RWHS}\left(Y_{i}\right)=1$

Then OGSY $\left(Y_{i}\right)=\operatorname{GSY}\left(Y_{i}\right)+\operatorname{RWHS}\left(Y_{i}\right)$

Here, the Table 1 describes the pseudo code for the calculation of optimal green score calculation.

Table 1. Pseudo code for calculating the green score

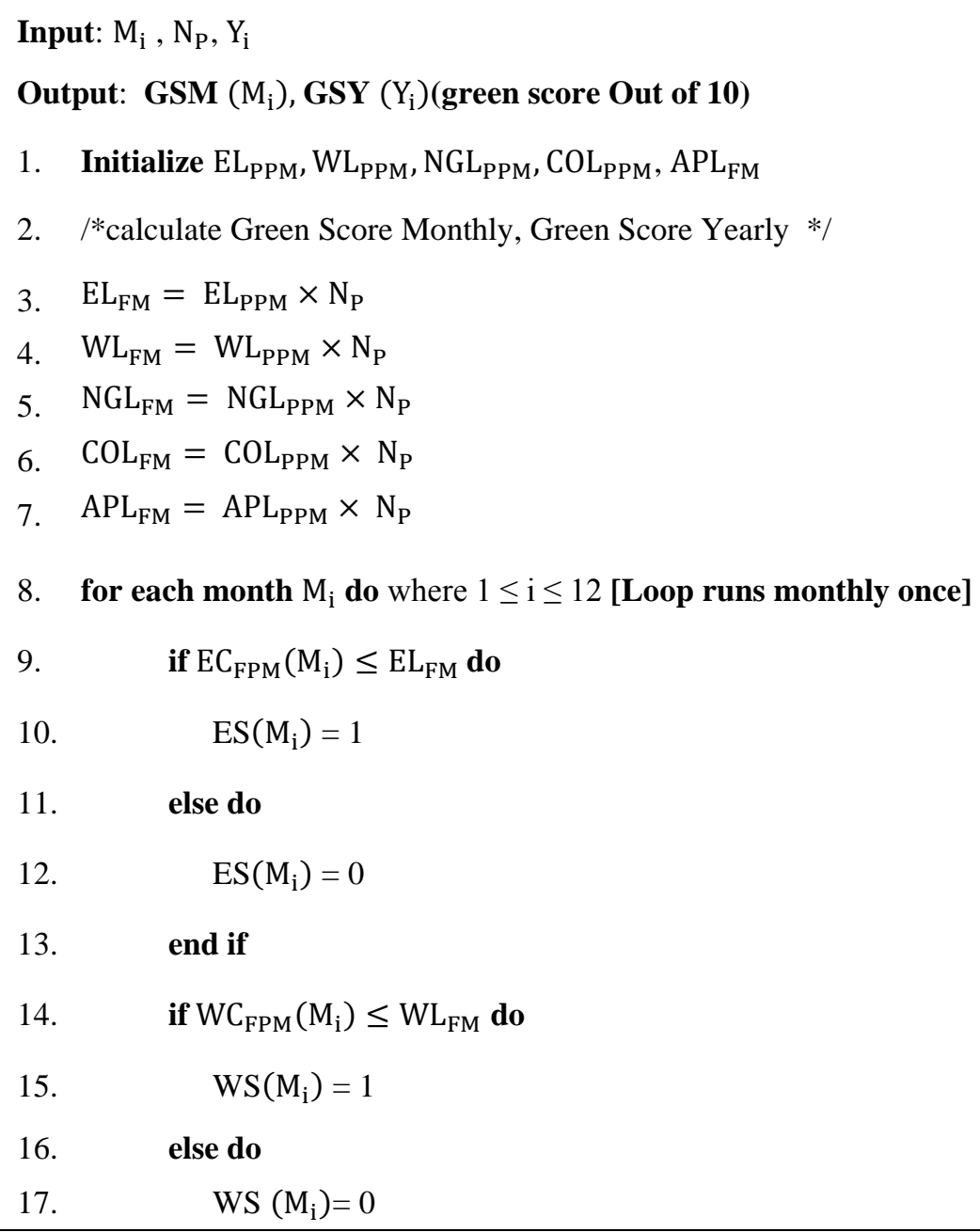




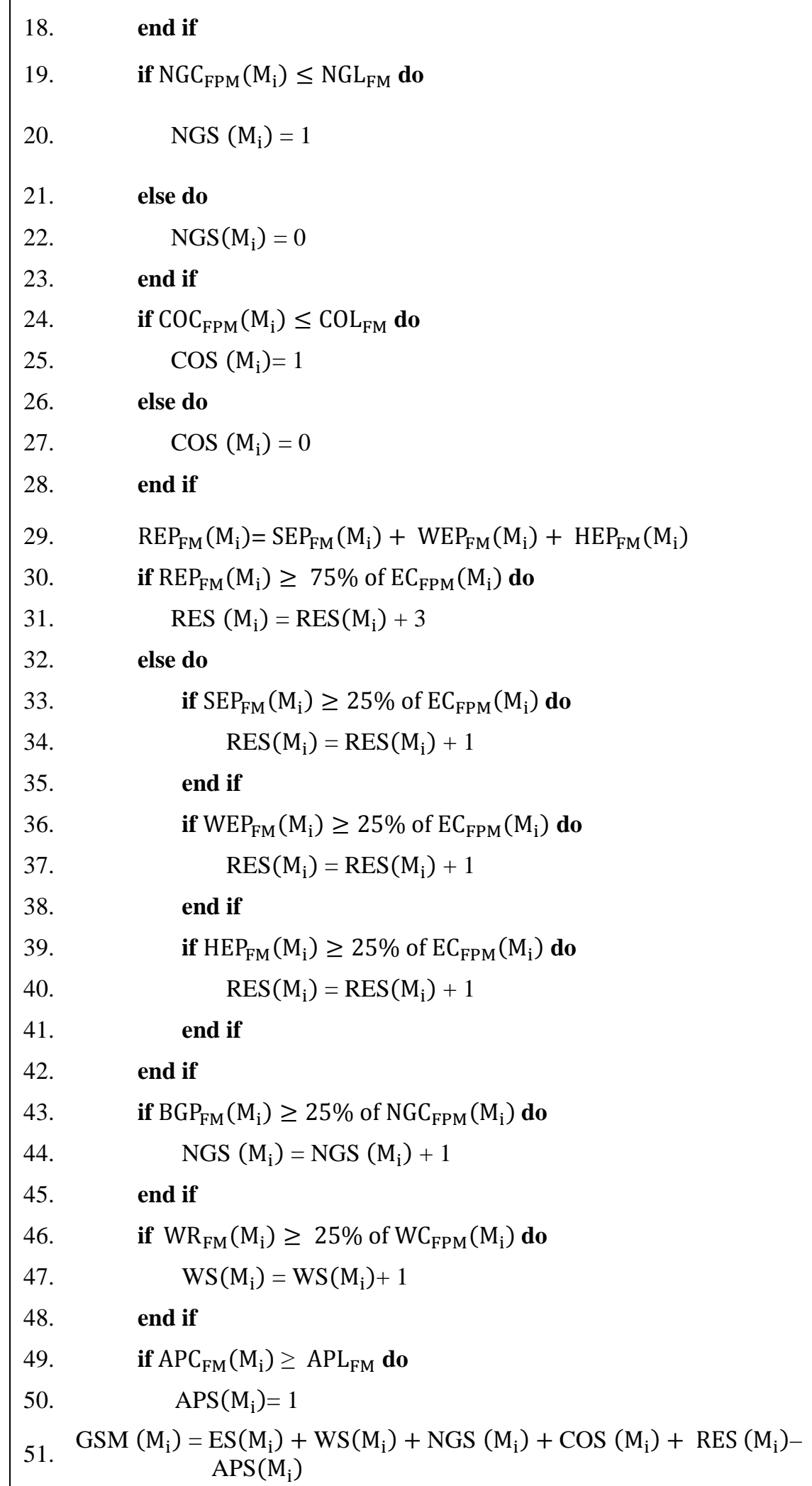




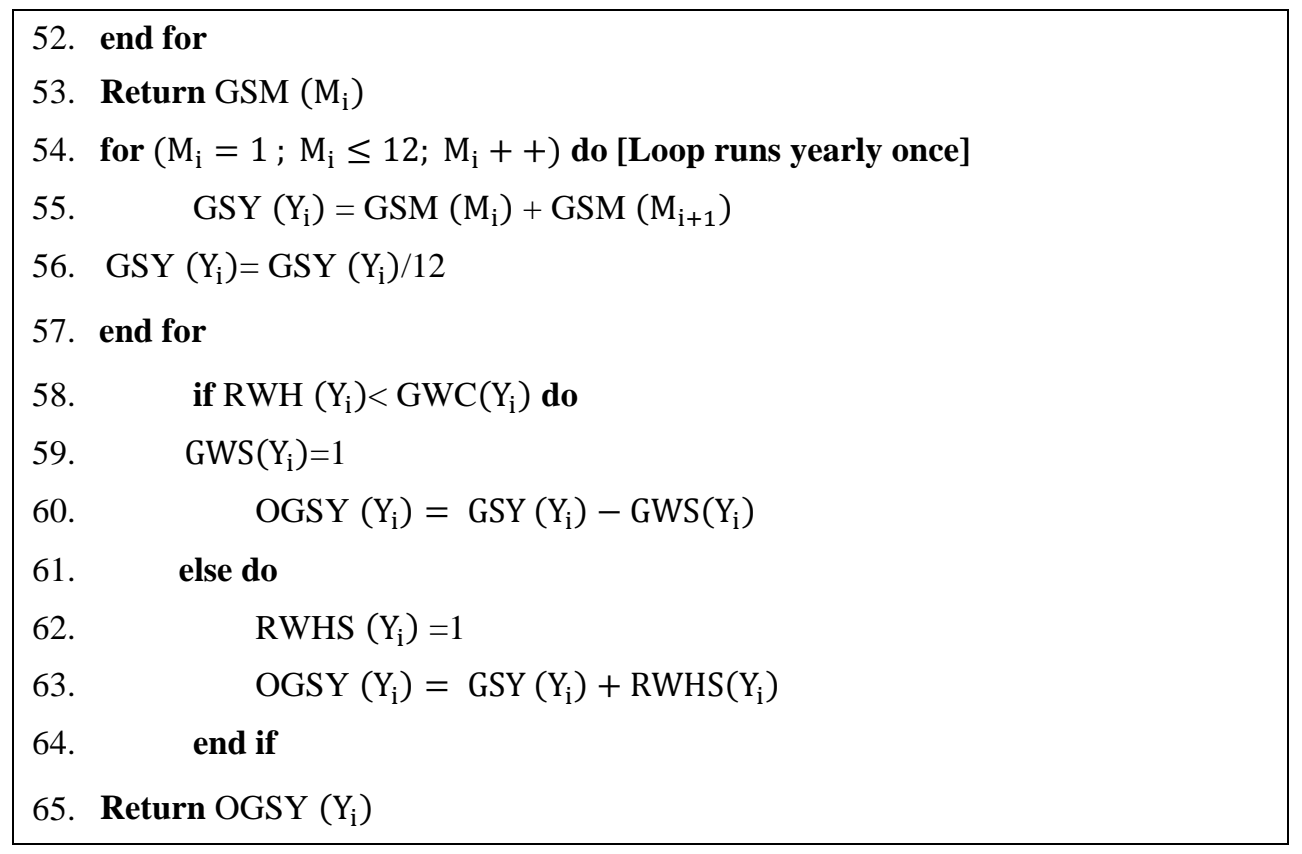

\section{Implementation}

Table 2. Implementation information

\begin{tabular}{|c|c|c|c|c|}
\hline Reference & $\begin{array}{l}\text { Resources/ } \\
\text { Nodes }\end{array}$ & Microcontrollers & Sensors & $\begin{array}{l}\text { Communication } \\
\text { platforms }\end{array}$ \\
\hline [19] & Green Meter & $\begin{array}{l}\text { Arduino BT (Bluegiga WT11) } \\
\text { ATemga32u4 (16MHz clock, 32KB flash } \\
\text { memory, 2.5KB SRAM) } \\
\text { Atheros AR9331 (400MHz, 64MB RAM, } \\
\text { 16MB flash) }\end{array}$ & - & $\begin{array}{l}\text { IEEE } 802.11 \\
\text { IEEE } 802.15\end{array}$ \\
\hline [24] & Air & $\begin{array}{l}\text { Arduino BT (Bluegiga WT11) } \\
\text { ATemga32u4 (16MHz clock, 32KB flash } \\
\text { memory, 2.5KB SRAM) } \\
\text { Atheros AR9331 (400MHz, 64MB RAM, } \\
\text { 16MB flash) }\end{array}$ & $\begin{array}{l}\text { MQ-7 and MQ- } \\
4 \text { gas sensors }\end{array}$ & $\begin{array}{l}\text { IEEE } 802.11 \\
\text { IEEE } 802.15\end{array}$ \\
\hline [25][26] & Electricity & $\begin{array}{l}\text { Atmega16L Microcontroller, } \\
\text { Arduino BT (Bluegiga WT11) }\end{array}$ & $\begin{array}{c}\text { ACS7102 } \\
\text { sensor }\end{array}$ & $\begin{array}{l}\text { IEEE } 802.11 \\
\text { IEEE } 802.15\end{array}$ \\
\hline [27] & Water & $\begin{array}{l}\text { Arduino Pro Mini, } \\
\text { ATmega328, 3.3V Flash Memory 32KB, } \\
\text { 8MHz Microcontroller }\end{array}$ & Flow Meter & Zigbee, 802.15.4 \\
\hline [28][29] & Crude oil & $\begin{array}{l}\text { Arduino BT } \\
\text { Bluegiga WT11 } \\
\text { NodeMCU (ESP8266) }\end{array}$ & $\begin{array}{l}\text { Ultrasonic } \\
\text { sensor }\end{array}$ & $\begin{array}{l}\text { IEEE } 802.11 \\
\text { IEEE } 802.15\end{array}$ \\
\hline [30] & Gas & $\begin{array}{l}\text { Arduino BT } \\
\text { Bluegiga WT11 } \\
\text { ATmega328 Microcontroller }\end{array}$ & Load sensor & $\begin{array}{l}\text { IEEE } 802.11 \\
\text { IEEE } 802.15\end{array}$ \\
\hline
\end{tabular}

Table 2 describes the components for the implementation of the green home architecture. The Table 2 contains appropriate microcontrollers, sensors and communication platform for the estimation of consumption and production of resources. 
Blynk is an iOS and Android-based application interface designer, guaranteeing the controlling of numerous controllers like Arduino, Raspery Pi and ESP8266 by means of web. This program, a graphics interface can be created for projects inside the most limited timeframe conceivable by essentially utilizing Widgets, without the need to compose any code. Blynk isn't reliant on a specific regulator, yet rather, it can work in viable with the controllers of different organizations. It offers inexpensive solutions for project designers, while giving these clients the occasion to profit by the cloud administration of Blynk, also.

In this section, we simulate the estimation of the optimal green score OGSY for the year 2019 based on the calculation of monthly green score GSM $\left(M_{i}\right)$. Here, $M_{i}$ describes the month for which the green score is calculated where ' $i$ ' ranges from 1 to 12 indicates a month from January to December. The objective is to find out the optimal green score of a family and recommend tax relaxation based on the obtained OGSY.

\subsection{Initialization}

Initially, the Table 3 describes a family's monthly usage of electricity $E L_{P P M}$, water $W L_{P P M}$, natural gas NGLPPM and crude oil COL $L_{P P M}$ for the month of January $\left(M_{1}\right)$. The Electricity usage limit allowed for a family per month $\mathrm{EL}_{\mathrm{FM}}$ is estimated as $500 \mathrm{KWH}$ by multiplying the monthly usage limit of electricity per capita ELPPM $(100 \mathrm{KWH})$ with the number of persons in the family $\mathrm{N}_{\mathrm{P}}=5$. Likewise, the water usage limit allowed for a family per month $\mathrm{WL}_{\mathrm{FM}}$ is calculated as 750 litres by multiplying the monthly usage limit of water per capita $W L_{P P M}$ with the number of persons in the family $\mathrm{N}_{\mathrm{P}}$. In the same way, the cooking gas limit allowed for a family per month $\mathrm{NGL}_{\mathrm{FM}}$ is calculated as 0.56 cubic feet by multiplying the monthly usage limit of natural gas per capita NGL $L_{P P M}$ with the number of persons in the family $\mathrm{N}_{\mathrm{P}}$. The crude oil usage limit allowed for a family per month $\mathrm{COL}_{\mathrm{FM}}$ is calculated as 80 litres by multiplying the monthly usage limit of crude oil per capita COL $L_{P P M}$ with the number of persons in the family $N_{P}$. After all, the air pollution limit set for the family is 50 AQI for every month of a year.

Table 3. Initialization and Calculation of Resource Usage limit per month

\begin{tabular}{|c|c|c|c|}
\hline Resource & $\begin{array}{l}\text { Per Capita Resource Usage } \\
\text { Limit/Month }\left(\mathrm{M}_{1}\right)\end{array}$ & $\begin{array}{l}\text { Number of } \\
\text { Persons in the } \\
\text { Family }\left(\mathrm{N}_{\mathrm{P}}\right)\end{array}$ & $\begin{array}{c}\text { Resource Usage Limit for a } \\
\text { Family/Month }\left(M_{1}\right)\left(=L_{P P M} \times N_{P}\right)\end{array}$ \\
\hline Electricity & $\mathrm{EL}_{\mathrm{PPM}}=100 \mathrm{KWH}[31]$ & 5 & $\mathrm{EL}_{\mathrm{FM}}=500 \mathrm{KWH}$ \\
\hline Water & $\mathrm{WL}_{\mathrm{PPM}}=150$ Litres $[32]$ & 5 & $\mathrm{WL}_{\mathrm{FM}}=750$ Litres \\
\hline Natural Gas & $\mathrm{NGL}_{\mathrm{PPM}}=0.112$ Cubic Feet [33] & 5 & $\mathrm{NGL}_{\mathrm{FM}}=0.56$ Cubic Feet \\
\hline Crude Oil & $\mathrm{COL}_{\mathrm{PPM}}=16$ Litres [34] & 5 & $\mathrm{COL}_{\mathrm{FM}}=80$ Litres \\
\hline Air Pollution & & & $\mathrm{APL}_{\mathrm{FM}}=50 \mathrm{AQI}$ \\
\hline
\end{tabular}

Based on the sensed data given in the Table 4, the monthly consumption of resources is compared with the respective usage limit fixed for each resource. The Table 4 describes the comparison of consumption and usage limit of electricity, water, natural gas and crude oil for the month of January $M_{1}$. The consumption of electricity $E C_{F P M}$, water $W C_{F P M}$, natural gas $N G C_{F P M}$ and crude oil $C O C_{F P M}$ are compared with their set usage limit $E L_{F M}, W L_{F M}, N G L_{F M}$, $C O L_{F M}$ respectively. The Table 4 also shows the score of electricity ES, natural gas NGS and 
crude oil COS are raised by 1 , because the consumption of those resources are the lesser than monthly usage limit. The water score WS is set as 0 because the water consumption $W C_{F P M}$ is higher than usage limit $W L_{F M}$.

Table 4. Score calculation of Electricity, Water, Natural gas and Crude oil

\begin{tabular}{|c|c|c|c|c|}
\hline Resource & $\begin{array}{c}\text { Resource Consumption } \\
\text { Sensed for the Month } \\
\text { January }\left(\mathrm{M}_{1}\right)\end{array}$ & $\begin{array}{c}\text { Resource Usage Limit } \\
\text { per Month }\end{array}$ & $\begin{array}{c}\text { Comparison of } \\
\text { Resource Consumption } \\
\text { versus Set Limit for } \mathrm{M}_{1}\end{array}$ & $\begin{array}{c}\text { Score for } \\
\text { the Month } \\
\mathrm{M}_{1}\end{array}$ \\
\hline Electricity & $\mathrm{EC}_{\mathrm{FPM}}=450 \mathrm{KWH}$ & $\mathrm{EL}_{\mathrm{FM}}=500 \mathrm{KWH}$ & $\mathrm{EC}_{\mathrm{FPM}}<\mathrm{EL}_{\mathrm{FM}}$ & $\mathrm{ES}=1$ \\
\hline Water & $\mathrm{WC}_{\mathrm{FPM}}=800 \mathrm{Litres}$ & $\mathrm{WL}_{\mathrm{FM}}=750 \mathrm{Litres}$ & $\mathrm{WC}_{\mathrm{FPM}}>\mathrm{WL}_{\mathrm{FM}}$ & $\mathrm{WS}=0$ \\
\hline $\begin{array}{c}\text { Natural } \\
\text { Gas }\end{array}$ & $\mathrm{NGC}_{\mathrm{FPM}}=0.5$ Cubic feet & $\mathrm{NGL}_{\mathrm{FM}}=0.56$ Cubic Feet & $\mathrm{NGC}_{\mathrm{FPM}}<\mathrm{NGL}_{\mathrm{FM}}$ & $\mathrm{NGS}=1$ \\
\hline Crude Oil & $\mathrm{COC}_{\mathrm{FPM}}=60 \mathrm{Litres}$ & $\mathrm{COL}_{\mathrm{FM}}=80 \mathrm{Litres}$ & $\mathrm{COC}_{\mathrm{FPM}}<\mathrm{COL}$ & $\mathrm{COS}=1$ \\
\hline
\end{tabular}

Table 5. Score calculation of Renewable Energy, Bio-Gas and Water Retreatment

\begin{tabular}{|c|c|c|c|c|}
\hline Resource & $\begin{array}{l}\text { Resource Produced } \\
\text { on the Month } \\
\text { January }\left(M_{1}\right)\end{array}$ & $\begin{array}{c}\text { Resource } \\
\text { Consumed for the } \\
\text { Month January } \\
\left(M_{1}\right) \\
\end{array}$ & $\begin{array}{l}\text { Comparison of Resource } \\
\text { Consumption versus } \\
\text { Production for } M_{1}\end{array}$ & $\begin{array}{l}\text { Score for the } \\
\text { Month } M_{1}\end{array}$ \\
\hline $\begin{array}{c}\text { Renewable } \\
\text { Energy } \\
\text { (Solar+wind+ } \\
\text { Hydro) } \\
\end{array}$ & $R E P_{F M}=250 \mathrm{KWH}$ & \multirow{4}{*}{$E C_{F P M}=450 \mathrm{KWH}$} & $R E P_{F M} \leq 75 \%$ of $E C_{F P M}$ & RES = 0 \\
\hline Solar Energy & $S E P_{F M}=125 \mathrm{KWH}$ & & $S E P_{F M} \geq 25 \%$ of $E C_{F P M}$ & RES = 1 \\
\hline Wind Energy & $W E P_{F M}=125 \mathrm{KWH}$ & & $W E P_{F M} \leq 25 \%$ of $E C_{F P M}$ & RES = 1 \\
\hline $\begin{array}{l}\text { Hydro-Electric } \\
\text { Energy }\end{array}$ & $H E P_{F M}=0 \mathrm{KWH}$ & & $H E P_{F M} \leq 25 \%$ of $E C_{F P M}$ & $\mathbf{R E S}=\mathbf{0}$ \\
\hline Bio-Gas & $\begin{aligned} B G P_{F M} & =0.15 \text { Cubic } \\
& \text { feet }\end{aligned}$ & $\begin{array}{c}N G C_{F P M}=0.5 \text { Cubic } \\
\text { feet }\end{array}$ & $\mathrm{BGP}_{\mathrm{FM}} \geq 25 \%$ of $\mathrm{NGC}_{\mathrm{FPM}}$ & $\mathrm{NGS}=1$ \\
\hline $\begin{array}{c}\text { Water } \\
\text { Retreatment }\end{array}$ & $\mathrm{WR}_{\mathrm{FM}}=0$ Litres & $\mathrm{WL}_{\mathrm{FM}}=750$ Litres & $\mathrm{WR}_{\mathrm{FM}} \geq 25 \%$ of $\mathrm{WC}_{\mathrm{FPM}}$ & $\mathrm{WS}=0$ \\
\hline
\end{tabular}

The Table 5 describes the resources, resources produced, resources consumed and their score based on the comparison result for the month of January $\left(M_{1}\right)$. First, the collective production of the three renewable energies $\left(\mathrm{REP}_{\mathrm{FM}}\right)$ solar, wind and hydro-electric power is compared with the electricity consumption of the month $\mathrm{EC}_{\mathrm{FPM}}\left(\mathrm{M}_{1}\right)$. If $\mathrm{REP}_{\mathrm{FM}}$ is greater than $75 \%$ of $\mathrm{EC}_{\mathrm{FPM}}$, the RES will be lift up by 3 . But the comparison result shows $\mathrm{REP}_{\mathrm{FM}}$ is lesser than $75 \%$ of $\mathrm{EC}_{\mathrm{FPM}}$ and it leads to no change on the RES of the month $\left(\mathrm{M}_{1}\right)$. Likewise, the comparison has done between the monthly production of individual renewable energies like solar $\mathrm{SEP}_{\mathrm{FM}}$, wind $\mathrm{WEP}_{\mathrm{FM}}$, hydro-electric $\mathrm{HEP}_{\mathrm{FM}}$ with $25 \%$ of the monthly electricity consumption $\mathrm{EC}_{\mathrm{FPM}}$. The individual comparison results show only two of three renewable energies $\mathrm{SEP}_{\mathrm{FM}}$ and $\mathrm{WEP}_{\mathrm{FM}}$ are greater than $25 \%$ of $\mathrm{EC}_{\mathrm{FPM}}$ and it leads to the improvement of RES by 2. Similarly, the other resources like $\mathrm{BGP}_{\mathrm{FM}}$ and $\mathrm{WR}_{\mathrm{FM}}$ are compared with $25 \%$ of $\mathrm{NGC}_{\mathrm{FPM}}$ and $25 \%$ of $\mathrm{WC}_{\mathrm{FPM}}$ respectively. This comparison results NGS to 1 and WS 
to 1 as $\mathrm{BGP}_{\mathrm{FM}}$ is greater than $25 \%$ of $\mathrm{NGC}_{\mathrm{FPM}}$ and $\mathrm{WR}_{\mathrm{FM}}$ is lesser than $25 \%$ of $\mathrm{WC}_{\mathrm{FPM}}$ respectively.

Table 6. Calculation of Air Pollution score

\begin{tabular}{|c|c|c|c|c|}
\hline Pollution & $\begin{array}{c}\text { Pollution Caused } \\
\text { on the Month } \\
\text { January }\left(\mathrm{M}_{1}\right)\end{array}$ & $\begin{array}{c}\text { Pollution Limit } \\
\text { per Month }\end{array}$ & $\begin{array}{c}\text { Comparison for the } \\
\text { Month } \mathrm{M}_{1}\end{array}$ & $\begin{array}{c}\text { Score for the } \\
\text { Month } \mathrm{M}_{1}\end{array}$ \\
\hline $\begin{array}{c}\text { Air } \\
\text { Pollution }\end{array}$ & $\mathrm{APC}_{\mathrm{FM}}=45 \mathrm{AQI}$ & $\mathrm{APL}_{\mathrm{FM}}=50 \mathrm{AQI}$ & $\mathrm{APC}_{\mathrm{FM}}\left(\mathrm{M}_{\mathrm{i}}\right) \leq \mathrm{APL}_{\mathrm{FM}}$ & $\mathrm{APS}=0$ \\
\hline
\end{tabular}

As per the Table 6, the $\mathrm{APC}_{\mathrm{FM}}$ and $\mathrm{APL}_{\mathrm{FM}}$ are getting compared to estimate the APS of the month $M_{1}$. Based on the green score algorithm, the APS is set to zero because the air pollution caused (45 AQI) is under the permissible pollution limit of $50 \mathrm{AQI}$.

The green score of the month January GSM $\left(M_{1}\right)$ can be calculated using the equation 7 as below,

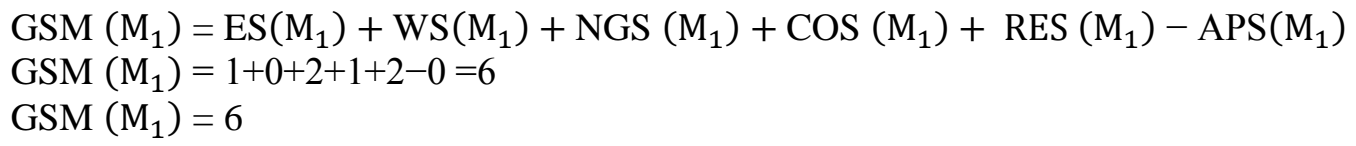

The graphical representation of the actual/obtained resource score versus maximum resource score for the month $\mathrm{M}_{1}$ is displayed in the Fig. 6 .

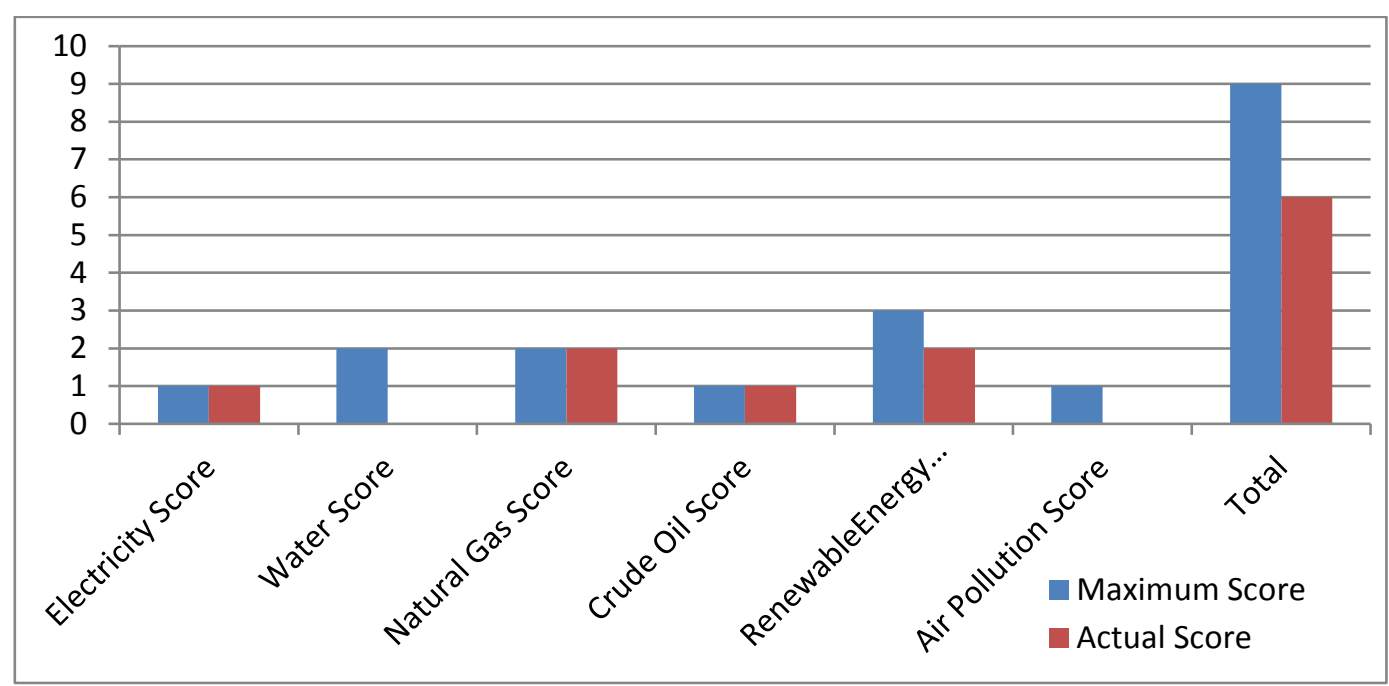

Fig. 6. Actual resource score versus maximum resource score of the month $M_{1}$.

The tabulation of Month-wise calculated green score GSM $\left(\mathrm{M}_{\mathrm{i}}\right)$ and yearly green score GSY (2019) is represented in the Table 7.

The Table 7 and Fig. 7 represents the estimated green score of all the month of 2019 and the yearly green score GSY (2019). Green score for the year 2019 GSY(2019) can be estimated by taking average of the sum of all the twelve-month green score (GSM) values. The yearly performance can be estimated by considering the monthly performance. 
Table 7. Calculation of yearly green score of the year 2019

\begin{tabular}{|c|c|c|}
\hline GSM & Month & Green Score \\
\hline GSM $\left(M_{1}\right)$ & January & 6 \\
\hline $\operatorname{GSM}\left(\mathrm{M}_{2}\right)$ & February & 7 \\
\hline $\operatorname{GSM}\left(\mathrm{M}_{3}\right)$ & March & 6 \\
\hline $\operatorname{GSM}\left(\mathrm{M}_{4}\right)$ & April & 5 \\
\hline $\operatorname{GSM}\left(\mathrm{M}_{5}\right)$ & May & 7 \\
\hline $\operatorname{GSM}\left(\mathrm{M}_{6}\right)$ & June & 7 \\
\hline $\operatorname{GSM}\left(\mathrm{M}_{7}\right)$ & July & 6 \\
\hline GSM $\left(M_{8}\right)$ & August & 7 \\
\hline $\operatorname{GSM}\left(\mathrm{M}_{9}\right)$ & September & 6 \\
\hline $\operatorname{GSM}\left(\mathrm{M}_{10}\right)$ & October & 6 \\
\hline $\operatorname{GSM}\left(M_{11}\right)$ & November & 7 \\
\hline $\operatorname{GSM}\left(\mathrm{M}_{12}\right)$ & December & 6 \\
\hline & Total $=$ & 76 \\
\hline \multicolumn{2}{|c|}{ GSY (2019) = Total/12 } & 6.34 \\
\hline
\end{tabular}

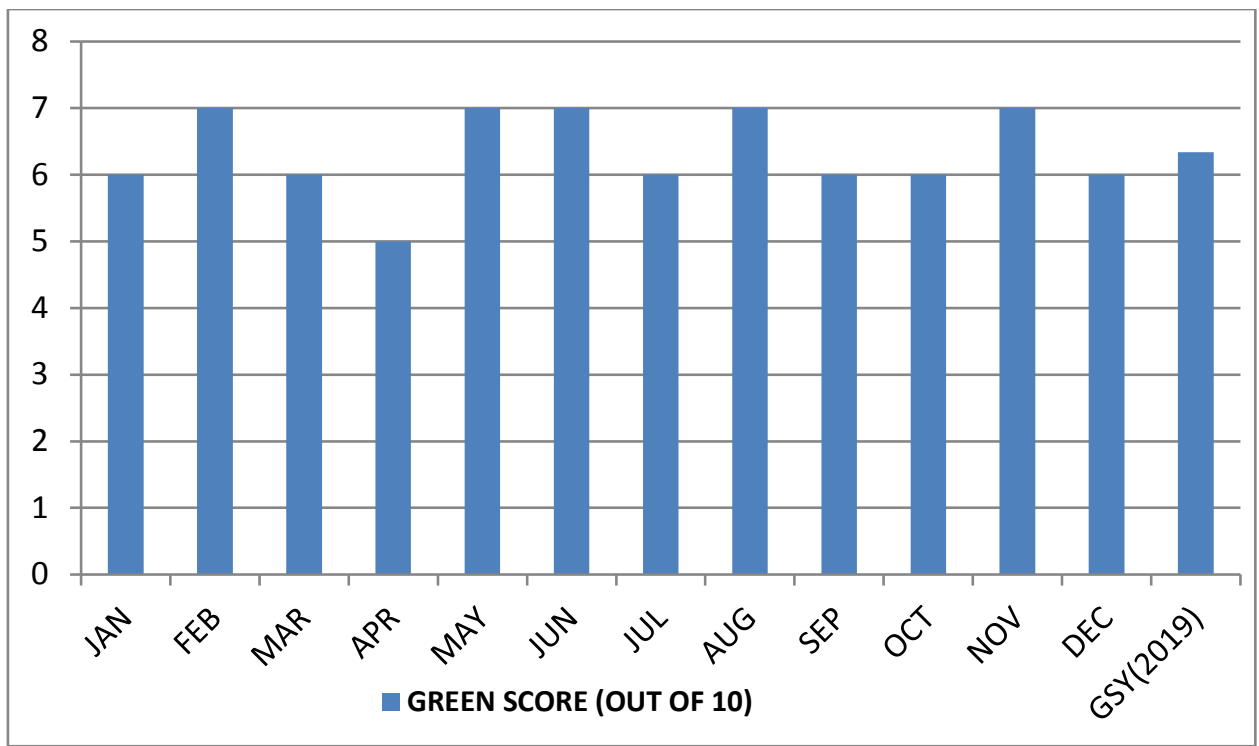

Fig. 7. Graphical representation of GSM and GSY(2019).

\subsection{Calculation of Optimal Green Score}

Table 8. Calculation of RWHS of 2019

\begin{tabular}{|c|c|c|c|c|}
\hline Resource & $\begin{array}{c}\text { Rain Water } \\
\text { Harvested on the } \\
\text { Year 2019 }\end{array}$ & $\begin{array}{c}\text { Ground Water } \\
\text { Consumed on the } \\
\text { Year 2019 }\end{array}$ & $\begin{array}{c}\text { Comparison of water } \\
\text { Consumed versus } \\
\text { harvested for 2019 }\end{array}$ & $\begin{array}{c}\text { Rain Water } \\
\text { Harvested } \\
\text { Score of 2019 }\end{array}$ \\
\hline Water & RWH = 15000 Litres & GWC = 5000 Litres & RWH > GWC & RWHS $=1$ \\
\hline
\end{tabular}


Based on the Table 8, the rain water harvested is higher than the ground water consumed during the year 2019. So, the scenario 2 will execute to estimate the optimal green of the year 2019.

\section{Scenario 2 (RWH (2019)>GWC(2019))}

As per the Table 8, the rain water harvested on the year (RWH (2019) is higher than the ground water consumption of the same year, so the rain water harvest score RWHS will be raised to 1 . Now by executing scenario 2, the optimal green score can be optimized by adding RWHS(2019) with GSY (2019) as in the equation 10.

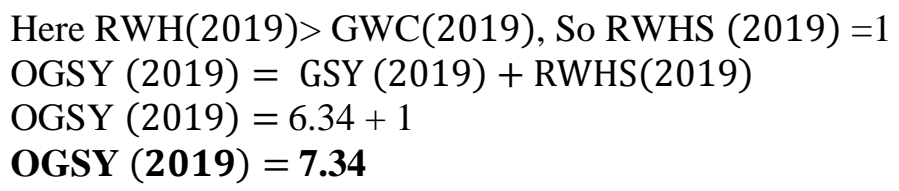

Hence, the said family got optimal green score of 7.34 out of 10 for the year 2019 and the same is forwarded for tax concession.

\section{Recommendations}

Climate change and sustainability issues continue to gain headlines, and the likelihood of costs being imposed on carbon dioxide emissions in developed countries has profoundly changed the economic outlook of renewable energy sources. Making the shift from fossil fuels to renewable energy lead the global governments, businesses, and consumers alike to examine all aspects of their environmental footprint and create strategies to become environmentally responsible and thrive in today's economic climate.

Table 9. Recommended tax exemption percentage based on Green Score

\begin{tabular}{|c|c|c|c|c|c|}
\hline Green Score & 5 to 5.99 & 6 to 6.99 & 7 to 7.99 & 8 to 8.99 & 9 \& above \\
\hline Tax Exemption & $10 \%$ & $20 \%$ & $30 \%$ & $40 \%$ & $50 \%$ \\
\hline
\end{tabular}

Climate change investment by countries has been raised tremendously in recent years. To tackle this issue, at least 60 countries currently use several policies to promote renewable power generation in their countries. Typically, a number of investments are used together for a complete renewable support scheme [21][22][23]. Though investments, subsidies provide financial assistance through grants, low-interest loans, to encourage the investment in a renewable energy production. It does not really concentrate on the proper working and maintenance of the household subsidy products. Here, our proposed smart home green score approach helps to provide appropriate operating subsidies which ensures the proper operation of the household subsidy product and it improves the lifetime of the renewable energy frameworks. This results in self-sufficiency in sustainable energy at every smart home. Thus, the primary aim of the green score framework is to increase the renewable energy production and make every home in the smart city to become self-sufficient in energy.

Instead of giving subsidies for infrastructure, we recommend to provide the operation subsidies based on the obtained optimal green score in the form of partial tax exemption or incentives as in the Table 9. The Table 10 shows the calculation of revised tax based on the recommended tax exemption earned through obtained green score. 
Table 10. The calculation of revised tax based on earned green score

\begin{tabular}{|l|l|}
\hline A person's yearly income (1) & INR 600000 \\
\hline Usual Tax exemption (2) & INR 250000 \\
\hline Remaining amount considered for tax (3)=(1)-(2) & INR 350000 \\
\hline Original tax to be paid (4)=10\% of (3) & INR 35000 \\
\hline \hline Green Score earned by his family & $\mathbf{7 . 3 4}$ \\
\hline $\begin{array}{l}\text { Recommended percentage of Tax Exemption (5) } \\
\text { (Based on the Table 9) }\end{array}$ & $\mathbf{3 0 \%}$ \\
\hline Actual Tax exemption (6)=(4)*(5) & INR 10500 \\
\hline Revised Tax (7)=(4)-(6) & INR 24500 \\
\hline
\end{tabular}

The maximum tax exemption will be given for only one person in a family and the income should not exceed INR 50000p/m. This will eliminate the excess claiming of tax exemption.

Further, our proposed green home framework monitors and reads the consumption of resources in appropriate units by using the suitable sensors. As in the Fig. 8 shown above, the sensed data can be stored and retrieved using a mass storage platform like cloud which can be utilized not only for the green score calculation but also for the household billing purpose of the consumed resources by the government agencies. This integrated platform can replace the manual billing, and directly benefits the government economically.

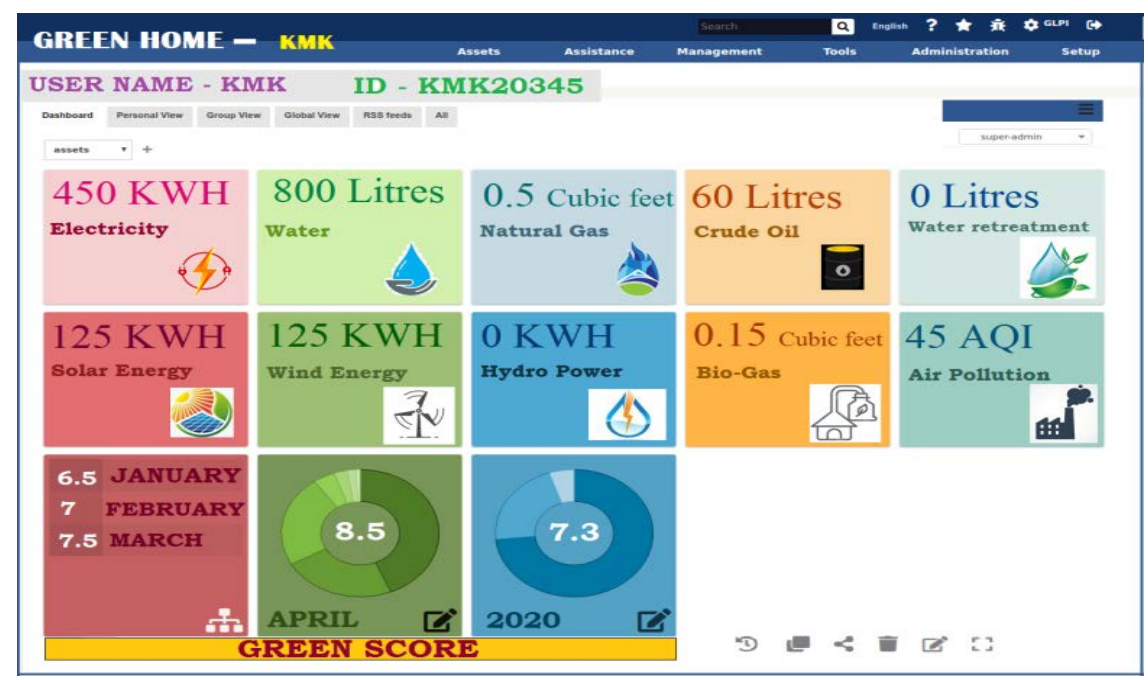

Fig. 8. User dashboard of green home framework

\section{Conclusion and Future Enhancement}

GHF Green home framework has a great potential to be the future assessing tool which can impact the most in household renewable energy production. This continuous energy assessment model benefits the users directly by tax incentives. This direct beneficiary model will appreciate and encourage all the citizens to deploy green home framework on their homes for green score calculation. This opportune scenario of the IoT will lead to the tremendous growth of household renewable energy generation which reduces the use of non-renewable 
resources usage largely. Hence, this initiates the dream transformation of cities from smart to green with least CO2 emission. In future, GHF and green score algorithm have to be modernized and upgraded to match industrial scenario monitoring. This will help to reduce the non-renewable resource for industrial usage and encourage the sustainable energy generation largely. Furthermore, it is essential to sort these technologies much affordable; dipping the costs of fabrication of these devices is important to make the benefits of this framework globally. Technology is the cause for all evils; let's eradicate the evils by using the technology wisely.

\section{References}

[1] Pachauri, R.K., Meyer, L.A., “Climate Change 2014: Synthesis Report,” Contribution of Working Groups I, II and III to the Fifth Assessment Report of the Intergovernmental Panel on Climate Change IPCC, Geneva, Switzerland, 2015, pp.151. Article (CrossRef Link)

[2] Sanchez-Miralles, A., Calvillo, C., Martín, F., Villar, J., "Use of renewable energy systems in smart cities," Use, Operation and Maintenance of Renewable Energy Systems, pp 341-370, May 2014.Article (CrossRef Link)

[3] Marlene Motyka, Scott Smith, Andrew Slaughter and Carolyn Amon, "Renewables (em)power smart cities,” Deloitte insights, Mar. 2019. Article (CrossRef Link)

[4] William D. Eggers and John Skowron, "Forces of change: Smart cities," Deloitte Insights, 22 Mar. 2018. Article (CrossRef Link)

[5] Y. Qian, D. Wu, W. Bao and P. Lorenz, "The Internet of Things for Smart Cities: Technologies and Applications," IEEE Network, vol. 33, no. 2, pp. 4-5, March/April 2019. Article (CrossRef Link)

[6] ManikandaKumaran, K., Chinnadurai, M., "Cloud-based robotic system for crowd control in smart cities using hybrid intelligent generic algorithm,” J Ambient Intell Human Comput, 11, 6293-6306, Mar. 2020. Article (CrossRef Link)

[7] G. Fortino, A. Guerrieri, and W. Russo, "Agent-oriented smart objects development," in Proc. of the 16th International Conference on Computer Supported CooperativeWork in Design (CSCWD '12), IEEE,Wuhan, China, pp. 907-912, May 2012. Article (CrossRef Link)

[8] J. Gubbi, R. Buyya, S. Marusic, and M. Palaniswami, "Internet of Things (IoT): a vision, architectural elements, and future directions,” Future Generation Computer Systems, vol. 29, no. 7, pp. 1645-1660, Sep. 2013. Article (CrossRef Link)

[9] S. Cirani et al., "A Scalable and Self-Configuring Architecture for Service Discovery in the Internet of Things," IEEE Internet of Things Journal, vol. 1, no. 5, pp. 508-521, Oct. 2014. Article (CrossRef Link)

[10] J.Han, C.-S. Choi, and I. Lee, "More efficient home energy management system based on ZigBee communication and infrared remote controls," IEEE Transactions on Consumer Electronics, vol. 57, no. 1, pp. 85-89, Feb. 2011. Article (CrossRef Link)

[11] D.-M. Han and J.-H. Lim, "Smart home energy management system using IEEE 802.15.4 and zigbee," IEEE Transactions on Consumer Electronics, vol. 56, no. 3, pp. 1403-1410, Aug. 2010. Article (CrossRef Link)

[12] J. Byun, I. Hong, and S. Park, "Intelligent cloud home energy management system using household appliance priority based scheduling based on prediction of renewable energy capability," IEEE Transactions on Consumer Electronics, vol. 58, no. 4, pp.1194-1201, Nov. 2012.

Article (CrossRef Link)

[13] G. Fortino, A. Guerrieri, G. M. P. O’Hare, and A. Ruzzelli, “A flexible building management framework based on wireless sensor and actuator networks," Journal of Network and Computer Applications, vol. 35, no. 6, pp. 1934-1952, Aug. 2012. Article (CrossRef Link) 
[14] D.Niyato, L. Xiao, and P.Wang, "Machine-to-machine communications for home energy management system in smart grid,” IEEE Communications Magazine, vol. 49, no. 4, pp. 5359, Apr. 2011. Article (CrossRef Link)

[15] Q. Hu and F. Li, "Hardware design of smart home energy management system with dynamic price response,” IEEE Transactions on Smart Grid, vol. 4, no. 4, pp. 1878-1887, Dec. 2013. Article (CrossRef Link)

[16] Kumaran, K.M., Chinnadurai, M., “A Competent Ad-hoc Sensor Routing Protocol for Energy Efficiency in Mobile Wireless Sensor Networks," Wireless PersCommun, 116, 829-844, 2021. Article (CrossRef Link)

[17] S. Manikandan, K. ManikandaKumaran, "Performance Analysis of Mobile Ad-Hoc Network RoutingProtocols using Network Simulator - 2,” COMPUSOFT, An international journal of advanced computer technology, vol. 3, no. 6, pp. 957-960, Jun. 2014. Article (CrossRef Link)

[18] Texas Gateway for online resources by Texas Education Agency (TEA). World Energy Use, Resource ID: ooulvKXE@4. [Online]. Available: https://www.texasgateway.org/resource/79-world-energy-use

[19] Kim, J., Byun, J., Jeong, D., Choi, M.-i., Kang, B., \& Park, S, “An IoT-based home energy management system over dynamic home area networks," International Journal of Distributed Sensor Networks, 11(10), Oct. 2015.

[20] M. TAŞTAN, "Internet of Things based Smart Energy Management for Smart Home," KSII Transactions on Internet and Information Systems, vol. 13, no. 6, pp. 2781-2798, Jun. 2019. Article (CrossRef Link)

[21] http://www.ourenergypolicy.org/wp-content/uploads/2016/03/KPMG-ENR-SustainabilityTaxes-and-Incentives.pdf

[22] Meier P, Vagliasindi M, Imran M, The design and sustainability of renewable energy incentives: an economic analysis, Washington, DC: International Bank for Reconstruction and Development, World Bank, 2015. Article (CrossRef Link)

[23] Sarangi, G. K, Green Energy Finance in India: Challenges and Solutions, ADBI Working Paper 863, Tokyo: Asian Development Bank Institute, Aug. 2018.

Article (CrossRef Link)

[24] I. B. Tijani, A. D. Almannaee, A. A. Alharthi and A. M. Alremeithi, "Wireless sensor node for indoor air quality monitoring system," in Proc. of 2018 Advances in Science and Engineering Technology International Conferences (ASET), Abu Dhabi, pp. 1-6, Jun. 2018. Article (CrossRef Link)

[25] F. Zhang and W. Li, "Power Consumption Monitor for Wireless Sensor Nodes," in Proc. of 2010 International Conference on Internet Technology and Applications, Wuhan, pp. 1-4, Sep. 2010. Article (CrossRef Link)

[26] M. TAŞTAN, "Internet of Things based Smart Energy Management for Smart Home," KSII Transactions on Internet and Information Systems, vol. 13, no. 6, pp. 2781-2798, Jun. 2019. Article (CrossRef Link)

[27] Alves, Arnon Jadir Rodrigues, Manera, Leandro Tiago, \& Campos, Marcel Veloso, "Lowcost wireless sensor network applied to real-time monitoring and control of water consumption in residences,” Revista Ambiente \& Água, 14(6), e2407. Epub November 28, 2019.

Article (CrossRef Link)

[28] P. Manjunath and P. Gajkumar, "IoT Based Handy Fuel Flow Measurement," in Proc. of 2019 Third International conference on I-SMAC (IoT in Social, Mobile, Analytics and Cloud) (ISMAC), Palladam, India, pp. 80-83, Dec. 2019. Article (CrossRef Link)

[29] Khatun, R., Antor, S., Ullah, A. and Hossain, A, "Vehicle Fuel Activities Monitoring System Using IoT,” Advances in Internet of Things, 9, 63-71, Oct. 2019. Article (CrossRef Link)

[30] V. Tamizharasan, T. Ravichandran, M. Sowndariya, R. Sandeep and K. Saravanavel, "Gas Level Detection and Automatic Booking Using IoT," in Proc. of 2019 5th International Conference on Advanced Computing \& Communication Systems (ICACCS), Coimbatore, India, pp. 922-925, Jun. 2019. Article (CrossRef Link) 
[31] EIA(2020) U.S. Energy Information Administration. [Online]. Available: https://www.worldometers.info/electricity/

[32] EIA(2020) U.S. Energy Information Administration. [Online]. Available: https://www.worldometers.info/water/

[33] EIA(2020) U.S. Energy Information Administration. [Online]. Available: https://www.worldometers.info/gas/us-natural-gas/\#gas-consumption/

[34] EIA(2020) U.S. Energy Information Administration. [Online]. Available: https://www.worldometers.info/oil/oil-consumption-by-country/ 


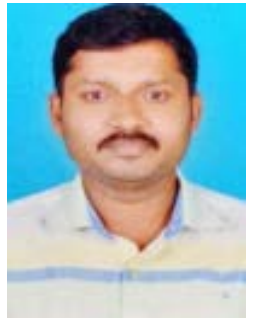

Dr. K. Manikanda Kumaran received his Doctor in Philosophy Ph.D. in Anna University, Chennai in the field of Cloud Robotics, Wireless Sensor Network. He completed his B.Tech. degree in Information Technology from Anna University, India in 2010 and M.E. degree in Computer Science and Engineering from Annamalai University, India, in 2012. Presently he is working as an Assistant Professor in the Department of Information Technology in E.G.S. Pillay Engineering College, Nagapattinam, India. He is professional member in ACM, IEEE, CSI, ISTE, etc. and his research interests including wireless sensor network, Internet of Things, mobile ad-hoc network and network security.

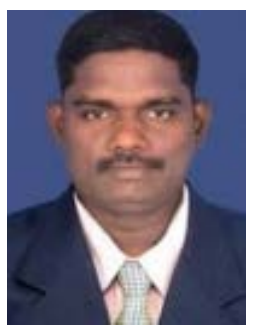

Dr. M. Chinnadurai is working as Professor and Head of CSE in E.G.S. Pillay Engineering College Nagapattinam. He completed his Ph.D. in Anna University, Chennai in the field of VLSI at Faculty of Information and Communication Engineering, Anna University, Chennai. He is professional member in IEEE, CSI, ISTE, etc. and his research work includes Artificial Intelligence, Network Security, Algorithms and Cloud Computing.

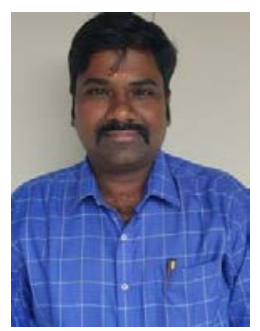

Dr. S. Manikandan received his Doctor in Philosophy Ph.D. in Anna University, Chennai in the field of Information and Communication Engineering. He completed his B.Tech. degree in Information Technology from Anna University, India in 2010 and M.E. degree in Computer Science and Engineering from Annamalai University, India, in2012. Presently he is working as a Head and Assistant Professor in the Department of Information Technology in E.G.S. Pillay Engineering College, Nagapattinam, India. He is professional member in ACM, CSI, ISTE, etc. and his research interests including deep learning, Internet of Things and network security.

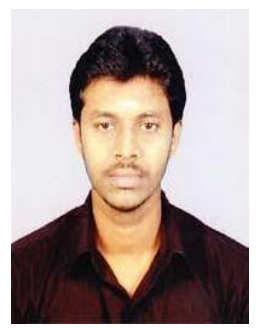

S. Palani Murugan is working as Assistant Professor of CSE in E.G.S. Pillay Engineering College Nagapattinam. He completed his B.E. degree in Computer Science and Engineering from Anna University, India in 2009 and M.E. degree in Computer Science and Engineering from Annamalai University, India, in 2012. He is professional member in CSI, ISTE, etc. and his research interests including wireless sensor network, Internet of Things and Cloud Computing.

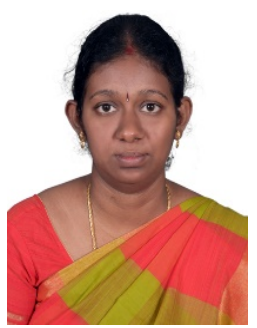

Dr. E. Elakiya received his Doctor in Philosophy Ph.D. in Anna University, Chennai in the field of Information and Communication Engineering and working as Assistant Professor of CSE in E.G.S. Pillay Engineering College Nagapattinam. She completed his B.Tech. degree in Information Technology from Anna University, India in 2010 and M.E. degree in Software Engineering from Anna University, India, in 2012. She is professional member in CSI, ISTE, etc. and his research interests including text mining, speech recognition and data mining. 